\title{
Inflation forces new tactics on US environmentalists
}

LAST SUMMER the environmental sciences board of the US National Academy of Sciences prepared a list of topics requiring its attention. At the top of the list was the potential threat to schemes for environmental management and regulation posed by pressures on the economy, and the political measures which might arise.

The board's concern reflected a debate that has been simmering in Washington since President Carter's administration began its attempts earlier this year to take a "firm grip" on the problem of inflation. A major component of the ensuing debate has been whether environmental controls are inflationary; and if so, what should be done about them.

Concern among environmentalists erupted briefly at the beginning of the autumn when Mr Robert Strauss, then the administration's chief inflation fighter, let slip his view that environmental regulation was one of the first areas in which cut-backs could be made.

Since then the rhetoric has been softened. Administration economists now talk about the need to demonstrate the cost-effectiveness of proposed regulations; and both regulators and environmentalists have won a number of important battles. But they are now on the defensive.

On balance, 1978 has not been a bad year for environmentalist causes. Though backing away from some commitments, President Carter has put up a strong fight against many potentially damaging water projects opposed by groups such as the Sierra Club, and recently signed into law the preservation of large areas of Alaska.

Furthermore last week the Tennessee Valley Authority announced after years of opposition, that it was prepared to invest over $\$ 1$ billion to clean up air pollution at ten of its power plants, a settlement described by the Environmental Protection Agency as "the largest ever made with a major source of air pollution".

However just as four years ago environmental regulations were being blamed for the problems of increasing unemployment, so the same is now being widely said about their contribution to inflation; industry claims, for example, that meeting new controls means taking away money from more productive areas of investment.

In reply, environmentalists claim not only that such regulations make a very small contribution to the increase in the consumer price index--estimated at less than $0.5 \%$ - but that if factors such as reduced health care costs are taken into account, the benefits of pollution control measures outweigh the costs.

"Most important, I believe that the public wants those benefits and is prepared to pay for them," says Douglas M. Costle, administrator of EPA. A recent survey conducted by Resources for the Future found that $62 \%$ of those questioned were prepared to pay higher prices to reduce pollution.

But to answer the charges bcing laid against the regulators, convictions previously expressed in qualitative terms are now having to be quantified. "We need to focus more on the adequacy of data, their interpretation, the need for risk-benefit analysis from a systems view," says Dr Gilbert S. Omenn, assistant director of the President's Office of Science and Technology Policy.

This need is reflected in the shifting strategies of environmentalist groups. Initially reluctant to place quantifiable values on that which they are trying to defend, this is now becoming necessary to respond to proposed "anti-

\section{'We are going to insist on better data on the cost- effectiveness of environmental control measures. I do not see this as necessarily bad, unless the pendulum goes too far' -Prof John Cantlon}

inflation" measures. The Natural Resources Defense Council, for example, one of the strongest such groups, is setting up a working group on the economics of the environment, and others are moving in this direction.

A major problem, however, is that whereas the likely costs of any new regulation are relatively easy to predict, the same is not true for the other side of the equation. "There is no question that trying to get at the benefits side of the picture is a very much tougher job of analysis and study," says Professor John E. Cantion, professor of botany at Michigan State University, and chairman of the NAS's environmental sciences board.

"However it is something that needs to be done. The scientific community should not stand around wringing its hands, but should start getting research groups interested in the problem," he says.

"The climate in government and in industry broadly - and I would even say in society-is that we are going to insist on better data on the cost-effectiveness of environmental control measures. I do not see this as necessarily bad, unless the pendulum goes so far as to call into question genuine concerns about internalising the social costs of production."

Others are concerned at this happening. Speaking at a meeting last week organised by a group called Environmentalists for Full Employment, Ms Peggy Seminario, an industrial hygienist with the American Federation of Labour and Congress of Industrial Organisations (AFL-CIO), claimed that many companies were using inflation as an excuse to resist further regulation, often using suspect data to support their arguments.

"At the heart of the debates on cost estimates, there are not many numbers, and the numbers are not that good. In 1974 environmental impact statements claimed the cost of meeting proposed vinyl chloride standards would be between $\$ 65$ million and $\$ 90$ million; recently, after the standards were introduced, it has been estimated that the costs to industry of meeting the regulations was less than $\$ 1 / 2$ million."

But the increasing incursion of economics into the environmental debate is also raising difficult issues within the environmentalist movement. Some have argued, for example, that the price of energy should be allowed to rise so that solar energy, already environmentally preferable to more conventional sources, can become economically competitive as well.

Others dispute this strategy, claiming that any increase in energy prices has an unfair impact on the poor. "The net result of present policies is to force people at the low end of the income distribution to lose food to pay for solar energy," Dr Gar Alperovitz, codirector of the Exploratory Project for Economic Alternatives, told the EFFE meeting.

"It is time for the environmental movement to take responsibility for what it is saying. We must reconsider the relation between strategies on prices and the desirable goals of conservation; for example there are other ways of getting to solar energy than by supporting higher prices."

Whichever way the various debates go, they seem destined, in Washington at least, to be increasingly fought on a terrain of economic argument which few can afford to ignore. As one Congressional aide put it last week: "Economists now seem to be playing the same role in Washington that scientists used to play in the 1960s."

David Dickson 